\title{
LANGUAGE CONTACT AND CHANGE IN EASTERN BOTSWANA: NEW INSIGHTS FROM THE PRONOMINAL SYSTEM OF AN UNDOCUMENTED KALAHARI KHOE LANGUAGE
}

Lee J. Pratchett Institute for African Studies, Goethe-University Frankfurt pratchett@em.uni-frankfurt.de

Abstract: This study contributes to the documentation and description of the diversity of Kalahari Khoe languages in eastern Botswana. Kalahari Khoe languages have highly complex pronominal systems with extensive paradigms of portmanteau morphemes encoding person, gender, and number categories. This study focuses on Thabala Tchoe, an entirely undocumented Kalahari Khoe language. Features of the Thabala Tchoe pronominal system set it apart from descriptions of closely and more distantly related languages. In this paper, I offer a formal and functional analysis of these features, which include honorific and focus sensitive pronouns, and innovative forms which offer contemporary evidence for the historical development of the complex pronominal system. This analysis is explored against the background of historical contact patterns between different Kalahari Khoe speech communities and Tswana merafe, or 'clans', in region.

Keywords: Khoisan, Khoe, Thabala Tchoe, pronouns, language contact, number

\section{Introduction}

The Khoe languages of southern Africa have large inventories of personal pronouns due to a three-way distinction in the categories of person (first, second, third), number (singular, dual, plural) and gender (masculine, feminine, common). Some languages also exhibit a clusivity distinction. The most expansive Khoe system ever documented belongs to the extinct language !Ora, with twenty-five contrastive pronominal 
forms from a possible twenty-seven slots (Güldemann 2004: 299; cf. Meinhof 1930: 43). A rich documentary record of the pronoun inventories in many Khoe languages, dialects, and doculects has paved the way for robust historical-comparative analyses (see Vossen 1997; Güldemann 2004; forthcoming a). This paper contributes to the description of the scantly described Tshwa language complex (Kalahari Khoe branch, see classification below) with an analysis of the pronominal system of a previously undocumented lect, Thabala Tchoe. The variety exhibits interesting features, some of which appear to be undocumented in Tshwa or in Khoe languages generally.

This paper is structured as follows. In $\S 1.1$, I provide a brief overview of the Khoe languages, the current state of language classification and relevant typological features, followed by a brief description of personnumber-gender (PGN) marking in Khoe in $\S 1.2$. The Thabala Tchoe lect is introduced in $\$ 2.1$, including geographical and sociolinguistic contextualisation. A description of the Thabala Tchoe pronominal system follows in $\$ 2.2$, highlighting specifically the three features that are analysed in $\$ 3$. The section concludes with some remarks on Tshwa classification in light of the present research. A brief conclusion is given in $\S 4$.

\subsection{Khoe languages and classification}

Khoe languages are head-final with a subject-object-verb word order in basic clauses. In terms of phonology, Khoe languages have large inventories of phonemically contrastive click segments, although the languages on the eastern periphery of the language area, including Thabala Tchoe, have undergone significant click replacement and click loss (see e.g. Traill \& Vossen 1997; Fehn 2018). Khoe languages have grammatical gender with masculine, feminine, and common gender marked by portmanteau morphemes that also encode number and person categories.

The Khoe languages form one branch of Khoe-Kwadi, one of the three genealogically unrelated lineages historically referred to as 'Khoisan' (see Güldemann 2014 for classification). Spread across much of 
southern Africa in the past, today the largest Khoe language communities are found in Namibia and Botswana, with some small speech communities in South Africa and Zimbabwe. Khoe languages have been linked to the moribund language Kwadi in Angola to form the Khoe-Kwadi family (Güldemann 2004; Güldemann \& Elderkin 2010).

Tshwa is classified within the East Kalahari Khoe sub-branch of Kalahari Khoe, one of the two branches that form the Khoe lineage (Vossen 1997; see Figure 1). Internal classification has continued to develop to reflect the progress of the documentation of the East Kalahari Khoe. A case in point is the recent classification of Tshwa that is based primarily on the pronominal systems of six Tshwa lects (Fehn \& Phiri 2017: 106). The authors propose a two-way division of Tshwa varieties into Northern Tshwa composed of Gllabak'e, Tcire-Tcire and Tjwao, and Southern Tshwa composed of the lects Kua, Tsua and Cua. I return to the question of language classification in $§ 3.4$.
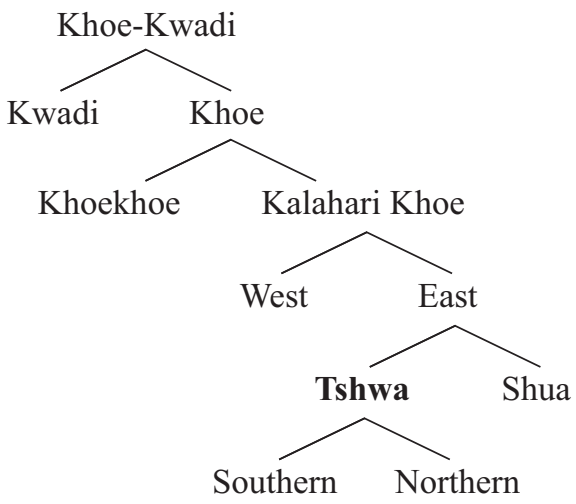

Figure 1. Classification of Tshwa

(after Fehn \& Phiri 2017; see also Vossen 1997)

\subsection{Person-gender-number marking in Khoe}

A salient feature of Khoe nominal morphology is the use of portmanteau morphemes that mark a three-way distinction in each of the 
person $\left(1^{\text {st }}, 2^{\text {nd }}, 3^{\text {rd }}\right)$, gender (common, feminine, masculine), and number (singular, dual, plural) categories, known as PGNs. PGN marking in the nominal domain varies considerably across Khoe languages, from obligatorily on all nouns and a handful of other targets in Standard Namibian Khoekhoe (Khoekhoe branch), to optionally in Ts'ixa (Kalahari Khoe branch, see Fehn 2016: 63-74). An example is given in (1), illustrating three different PGN-marked constituents. In the initial dependent clause, - -ù (3M.PL) is marked on a headless relative clause functioning as a nominal argument 'those who eat cattle' which itself includes the noun góe 'cow' marked by the accusative form of the $3^{\text {rd }}$ person feminine plural, $-d z a ̀$. The proceeding independent clause contains a subject pronominal base é marked by the $3^{\text {rd }}$ person feminine singular PGN - sì.

(1) Ts'ixa (Kalahari Khoe, Khoe, Khoe-Kwadi) (Fehn 2016: 63)

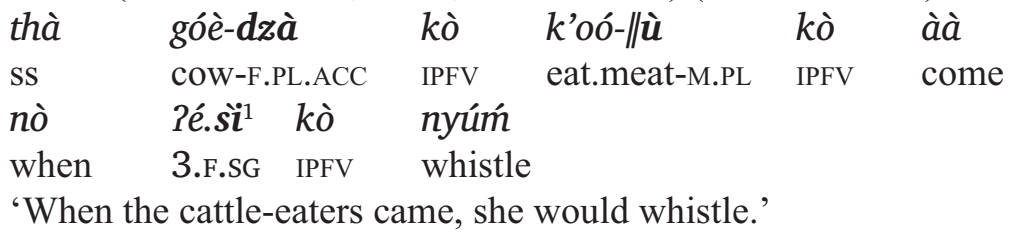

Vossen (1997: 367-377), based on an extensive comparative analysis of Khoe languages, reconstructs the PGN system of Proto-Khoe. The reconstructed system resembles contemporary Khoekhoe languages with fully elaborated paradigms of morphologically complex pronominal forms that are composed of a pronominal base and a PGN morpheme (see é.sì 3F.SG in the example above). Güldemann (2002; 2004; forthcoming a) proposes an alternative analysis. He suggests that the complex systems in modern Khoe languages developed out of a comparatively much simpler "minimal augmented" system and that the considerable divergence between Khoe and Kwadi is due to substrate interference and restructuring processes. Table 1 presents the PGN forms for ProtoKalahari Khoe following Güldemann's analysis, which is adopted here.

${ }^{1}$ A point is used in the transcription to mark the boundary between the pronominal base and PGN enclitic. 
In Tshwa varieties, nominal marking by PGNs is largely absent (Vossen 1997; 2013; Chebanne 2014; Fehn \& Phiri 2017). Thus, the most robust evidence of the PGN inventory comes from the pronominal system.

Table 1

The reconstructed PGN system of Proto-Kalahari Khoe

(Güldemann 2004: 297)

\begin{tabular}{|c|c|c|c|c|}
\hline & Common & Feminine & Masculine & \\
\hline 1 & $* t i, * t a$ & & & \\
2 & & $* s a$ & $* t s a$ & sG \\
3 & & $* s i$ & $* b i$ & \\
\hline 1 & $* k h o-m(u)$ & $* s a-m(u)$ & $* t s a-m(u)$ & DU \\
2 & $* k h o-d a-o$ & $* s a-d a-o$ & $* t s a-d a-o$ & \\
3 & $* k h o-d a$ & $* s a-d a$ & $* t s a-d a$ & \\
\hline 1 & $* t a-e$ & $* s a-e$ & $* ! a-e$ & PL \\
2 & $* t a-o$ & $* s a-o$ & $* ! a-o$ & \\
3 & $* n V$ & $* d i$ & $* ! a-u(>* ! u)$ & \\
\hline
\end{tabular}

\section{Person-gender-number marking in Thabala Tchoe}

We turn now to the pronominal system in Thabala Tchoe, an undocumented Tswha variety spoken by San hunter-gatherers on the edge of the Western Sandveld in the central Kalahari, Botswana. There are approximately one hundred speakers of the Thabala Tchoe variety across the settlements of Mabuo, Mogorosi, Motshegaletau, Thabala, and on the outskirts of Serowe, the administrative capital of the Central District (see Map 1). Data presented in this paper are taken from unpublished field notes following three field trips between 2016 and 2018 as part of the documentation project "A discourse-based documentation of San varieties in the Western Sandveld Region" funded by the Endangered Languages Documentation Programme (ELDP, SOAS). 


\subsection{The Thabala Tchoe}

As is commonly the case with Kalahari San communities, the Thabala Tchoe have numerous aliases, some of which are also used by other speech communities across Botswana. This includes Kua and the palatalised variants [t $\mathrm{fua}$ ], rendered orthographically both as tcua and cua in different sources. The term can be loosely translated as 'forager-huntergatherer' and is perceived negatively by some speech communities in north-eastern Botswana (Fehn, p.c.). On the ground, the most common labels encountered are Basarwa and Sesarwa, exonyms of Tswana origin (Bantu S30, Niger-Congo) that are used indiscriminately to refer to all hunter-gatherer communities and their languages. ${ }^{2}$ A commonly used label of self-reference is tchoe $/ \mathrm{t} \mathrm{h}^{\mathrm{h}} \mathrm{Oe} /$ (from *khoe 'person' in ProtoKhoe, Vossen 1997: 467). Within the community, the language is called tchoe k'ui, meaning 'person's language'.

To the west of Thabala, the phonological variant tshoe $/ \mathrm{ts}^{\mathrm{h}} \mathrm{oe} /$ is more common. These speakers are not representative of the same speech community and appear to have been resettled there in the late nineties from the Kweneng District further west. The lect is possibly comparable to Tsua as described in Mathes (2015, see also Chebanne 2014). On the edge of the Central Kalahari Game Reserve, the Diphuduhudu community also self-identifies using tchoe (and tcua). However, this is yet another speech community and there is low mutual intelligibility with Thabala Tchoe. Although both varieties exhibit some degree of palatalisation (i.e. $/ \mathrm{k}^{\mathrm{h}} \mathrm{Oe} />/ \mathrm{t} \mathrm{f}^{\mathrm{h}} \mathrm{Oe} /$ ), other phonological processes are not equally distributed across both varieties: for example, click replacement is not advanced in the Diphuduhudu lect. There appears to be almost no literature on the variety, although it may be comparable with the lect Cua described in Chebanne (2014). ${ }^{3}$

${ }^{2} \mathrm{mo}$-, $b a-, b o-$, and $s e$ - are Tswana agreement class prefixes for classes 1 (human singular), 2 (human plural), $2 \mathrm{a}$, and 7 , respectively.

${ }^{3}$ Valiente-Noailles (1993) reports a community at Ngware in the 1970s who identified as Bakwa. The community at Diphuduhudu, just slightly north of Ngware, were also heard referring to their language as Sekwa. The two terms are 


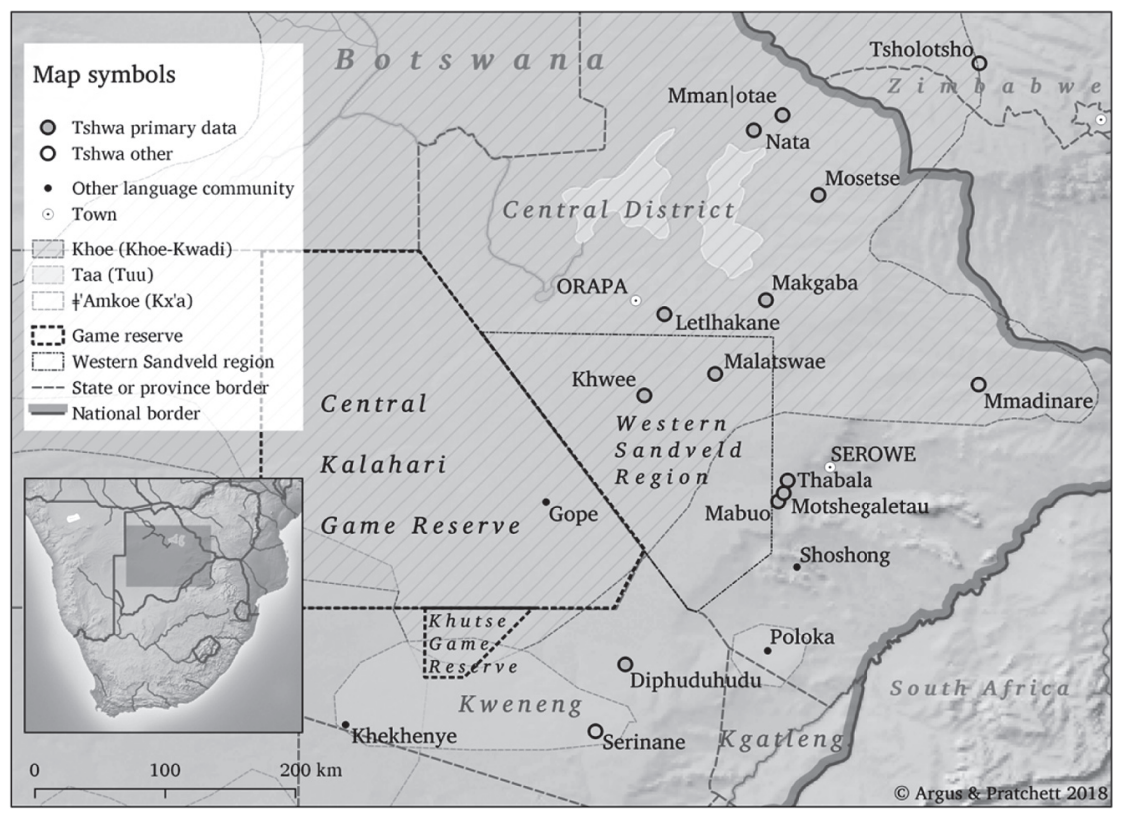

Map 1. Map of eastern Botswana and the Tshwa dialect cluster region

By far the most descriptive term of self-reference is Tcibi Tcua [t $\int i b i$ t $\left.\int u a\right]$, composed of tcibi 'a member of the Pedi clan' and tcua 'forager-hunter-gatherer'. The label recognises the historical status of this particular San community as malata or 'serfs' to the Pedi, SothoTswana pastoralists who migrated from the northern Transvaal in South Africa in the eighteenth and nineteenth centuries (Campbell et al. 2006: 198-199; Morton et al. 1989: xiii, 94). This explains why the area around Thabala is nowadays known locally as Bopedi, or 'Pedi country'. Thabala Tchoe speakers sometimes refer to their own language as Sepedi. On one occasion, a language informant spontaneously identified

perhaps related to the Kalanga word khwa 'bush', a language present in the area since the seventeenth century (see Campbell et al. 2006: 198), albeit to a lesser extent today. 
the variety in a recording as being Sepedi and could identify lexical and phonological cues that distinguished the variety from his own. He himself identified as a kwini kua or 'San of the Ngwato clan' (cf. Campbell et al. 2006: 198).

These labels attest to the subordinate status of Tshwa San and the historical socioeconomic ties between them and Tswana merafe or 'clans' such as the Kwena, Pedi and Ngwato (see e.g. Parsons 1974; Hitchcock \& Nangati 2000; Campbell et al. 2006). Historically, increasing cattle sizes brought more land under Tswana control, subjugating those who existed there. San labour was essential to the expansion of the cattle economy in Botswana and "it is not too farfetched to suggest that some of the Tswana states (e.g. the Bamangwato) existed primarily because of the availability of San labour" (Wilmsen 1989: 96-102; Campbell et al. 2006: 187). Tswana chiefs had "exclusive rights" (Campbell et al. 2006: 199) over their servants and their descendants, linking families to their masters for generations. This is significant given the conflict and schisms within the more powerful Tswana clans over the last two centuries, particularly within the Ngwato, that often resulted in the relocation people and cattle across central and north-eastern Botswana (e.g. Parsons 1993: 47, 51-52, 134-135). This history caused the relocation of different Tshwa speech communities across the region, sometimes repeatedly. In the seventies, Anthony Traill noted that the movement of people by the Ngwato clan was one of the main "complexities" of the region (Hitchcock 1978: appendix 28). This evaluation is as relevant today as it was fifty years ago. Given the extent of diversity within Kalahari Khoe and the complex history of the region, there is great need for transparent, descriptive nomenclature. Tcibi Tcua succinctly delineates a homogeneous speech community in space and time. Nevertheless, sensitive to the circumstances under which such terms originate, I refer to the speech community and their lect as Thabala Tchoe (henceforth Tchoe). Thabala reflects the groups claim of long-term presence in the area around the Thabala settlement and Tchoe 'person' is the most natural and neutral term of self-reference. 


\subsection{The pronominal system of Thabala Tchoe}

The complete system of personal pronouns in Tchoe is given in Table 2. Each form was elicited from three different speakers using frame sentences 'PRO see(s) a lion', 'the lion bites X', and 'the lion bites X dog', where X stands for a subject (nominative), object (accusative), or possessive (genitive) pronoun. The forms are also attested in a small corpus of naturalistic and elicited speech. Owing to insufficient knowledge on the tonal system, tone is unmarked.

With the exception of the $1^{\text {st }}$ person and $2^{\text {nd }}$ person singular, all personal pronouns are composed of two parts: the pronominal base and the PGN morpheme. Compare the examples (2) and (3). Example (2) shows a so-called simplex pronoun, composed of only the PGN ca ( $2 \mathrm{~F} . \mathrm{SG})$. In (3), the nominative pronoun e.ce (3F.SG) is composed of the pronominal base $e$ and a PGN suffix: $-c e$ in the nominative case and $-c i$ in the genitive case. Such pronouns are referred to as complex pronominal forms.
(2) ca ko xam mũu
2F.SG IPFV lion see
'You (F.) see a lion.'
(3)

$\begin{array}{llllll}\text { e.ce } & \text { thuuka } & \text { e.ci } & \text { \|loe-re } & \text { Poa } & \text { /q'ũu } \\ \text { 3F.SG } & \text { yesterday } & \text { 3F.SG.GEN } & \text { knee-PL } & \text { LOC } & \text { hurt }\end{array}$
'She hurt her knees yesterday.'

In Tchoe, a clusivity distinction exists in the $1^{\text {st }}$ person dual and plural paradigms, marked by a contrast in the pronominal base: $a$ for inclusive pronominal forms and $i$ for the exclusive equivalent. See examples (4a) and (4b).

\begin{tabular}{|c|c|c|}
\hline a. a.khabe & ko & xam \\
\hline C.DU.IN & IPFV & lion \\
\hline
\end{tabular}

\begin{tabular}{|c|c|c|c|}
\hline b. i.khabe & ko & Gaborone & Poa \\
\hline J.EX & IPFV & PN & LOC \\
\hline
\end{tabular}




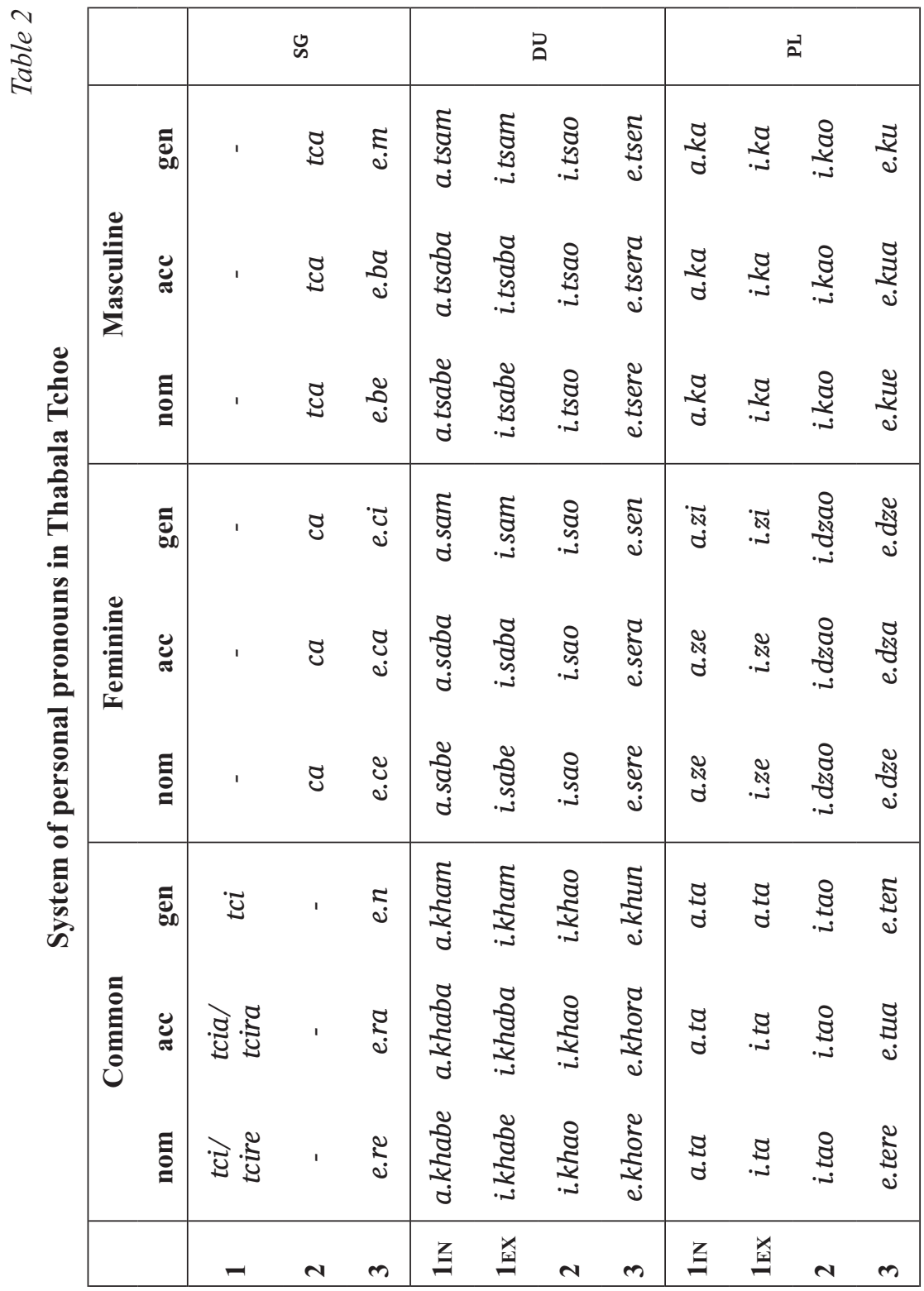


Case is never marked on $2^{\text {nd }}$ person PGN forms. For most $1^{\text {st }}$ and $3^{\text {rd }}$ person forms, case can be identified by segments at the end of the PGN morpheme: $-e$ for nominative, $-a$ for accusative, and morphemefinal nasal for genitive case, e.g. e.be 'he', e.ba 'him', and e.m 'his'. However, case distinctions are not universally marked. A three-way case distinction exists for all $3^{\text {rd }}$ person pronouns except for the feminine plural forms in which only a contrast between the nominative/genitive and accusative exists. A three-way case distinction is found in all $1^{\text {st }}$ person dual and $1^{\text {st }}$ person common plural pronouns. A two-way case distinction (NOM/ACC versus GEN) for the $1^{\text {st }}$ person feminine plural is attested but case is not marked at all for the masculine counterparts.

As aforementioned, most pronominal forms in Tchoe are composed of a pronominal base and the PGN morpheme. By contrast, hortative pronouns are formed using the respective genitive PGN morpheme without a pronominal base, as in (5).

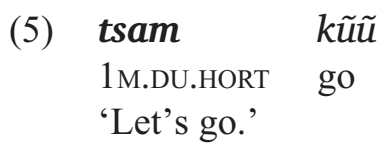

\subsection{On nominal marking in Thabala Tchoe}

Nominal marking in Tshwa languages is under-developed compared to other Khoe languages. The following description is not exhaustive and serves to facilitate the analysis of innovative features described in $\S 3$.

In Tchoe, PGNs are marked almost exclusively for human referents, such as with personal names and some kinship terms. As such, 'Lee' in (6) receives person-number-gender marking, but xam 'lion', seen previously in (4a), does not.

(6)

$\begin{array}{llll}\text { Lee-be } & \text { k'oo-xo } & \text { k'oo } & \text { taa } \\ \text { PN-M.SG } & \text { eat.meat-NMZ } & \text { eat.meat } & \text { NEG } \\ \text { 'Lee does not eat meat.' } & & \end{array}$

Anaphoric reference follows the same pattern. Thus, 'Lee' is referred to with a full pronominal form with a PGN marker, i.e. e.be (3M.SG), but non-humans are usually indexed using only the pronominal base. 
If sex is implicit in the noun, as in mama 'mother', or marked adnominally by $g / \mid a e$ 'female' and k'ao 'male', the noun is not marked by a PGN, as in (7).

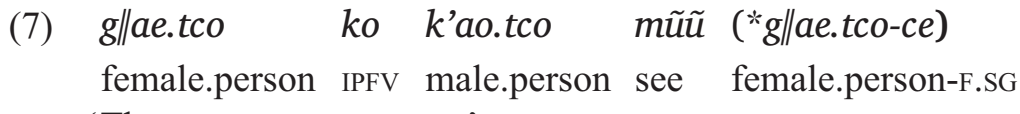

'The woman sees a man.'

Nominal, non-singular referents are marked uniformly, irrespective of animacy, with the plural markers -re (NOM), $-r a$ (ACC), and $-n$ (GEN), as in (8).

$\begin{array}{llll}\text { g\|ae.tco-re } \quad \text { ko } & \text { xam } & \text { mũũ } \\ \text { female.person-PL IPFV } & \text { lion } & \text { see } \\ \text { 'The women see a lion.' } & & \end{array}$

Naturalistic speech data also provides evidence of person-gendernumber marking in a possessive construction involving the associative marker de, as in tci de.tsere 'my ones' (3M.Du), and on numerals, as in (9). Referents must be human.

(9)

$\begin{array}{llllll}\text { ha-kue } & \text { ha-ba } & \text { tcuu } & \text { te } & \text { mona-kue } & \text { kũu } \\ \text { DEM-M.PL } & \text { DEM-M.SG.ACC } & \text { wake } & \text { and three-M.PL } & \text { go } \\ \text { Po ... } & \text { lam-tsere } & \text { Pae } & \text { hĩ } & & \\ \text { ? } & \text { two-M.DU } & \text { stay } & \text { remain } & & \end{array}$

'These ones wake him and then three of them run away...two remain.'

This section has provided a brief overview of the pronominal system and some central aspects of nominal morphology in Tchoe. In the next section, we turn to novel features of the Tchoe pronominal system.

\section{Innovations in the Thabala Tchoe pronominal system}

This section details three features of the Tchoe pronominal system that distinguish the lect from all other Tshwa varieties (for data on Khoe pronominal systems see Vossen 1997; 2013; for Tshwa specifically see Chebanne 2014; Fehn \& Phiri 2017). These include the referential 
honorific function of the plural pronoun for $3^{\text {rd }}$ person common gender (§3.1), focus-sensitive forms of the $1^{\text {st }}$ person singular pronoun (§3.2), and the innovation of morphologically complex pronominal forms for the $3^{\text {rd }}$ person common gender plural (§3.3). To the best of my knowledge, the first and the third feature are unattested in any other Khoe language. In light of these innovations, and following a brief comparison with other Tshwa lects, this section ends with a brief discussion on the position of Tchoe in the linguistic landscape (\$3.4).

\subsection{Pronominal honorification}

From a formal perspective, the set of $3^{\text {rd }}$ person pronominal forms in Tchoe - e.re, e.ra, e.n (see Table 2 above) - are unremarkable. Many Kalahari Khoe varieties attest identical or near-identical forms. The PGN in each case derives from the plural marker ${ }^{*} \mathrm{nV}$ in Proto-Khoe (Vossen 1997: 376-377). In some Kalahari Khoe languages, the suffix underwent phonological fortition (i.e. denasalisation) towards $-d V$ (Güldemann 2004: 262) and an allomorph $-r V$ also exists. Only the genitive form has not undergone this sound change, its conservatism perhaps due to its status as a dependent form.

It is from a functional perspective, as anaphoric index for singular referents, that these three non-singular pronouns become more interesting. Let us start by looking at the response to the elicited sentence 'he sees his dog', shown in (10).

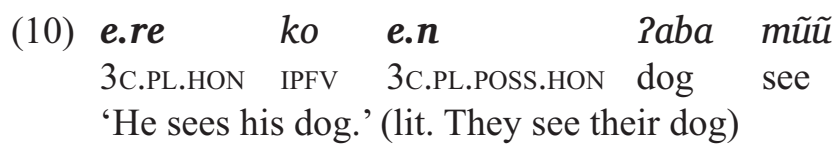

As the informant noted, the anaphoric pronoun in (10) could refer to either a man or a woman who is likely older or revered by the speaker. This explanation, and the additional examples below, suggest that these common gender plural PGNs have developed an honorification function as markers of social deixis (see e.g. Brown \& Levinson 1987: 276f). This is confirmed by the next utterance, 
this time from natural discourse. In the first line of the utterance, the speaker introduces two male referents by name and then refers to them both again individually using $3^{\text {rd }}$ person pronouns in the second line of the utterance. Only one of the referents, the speaker's older brother, receives the special use of plural marking, both on the proper name Ranamane as well as on the anaphoric pronoun; the second referent, Radinoko, receives no such marking. Note that in this example, the pronominal bases involve elements $x a$ and $n a$, which encode other deictic distinctions.

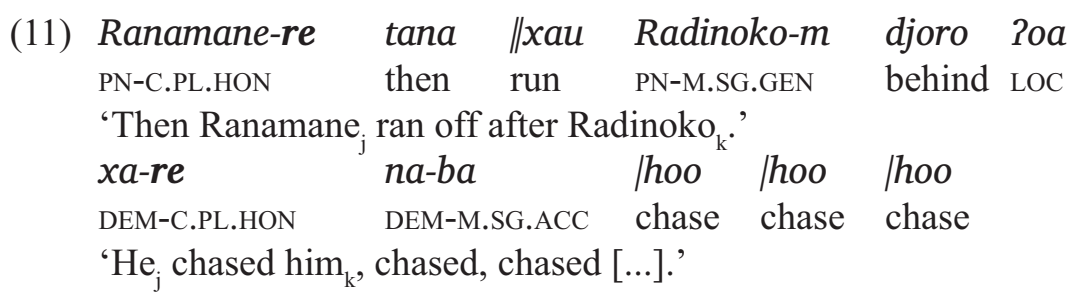

In this story about growing up with children from Tswana clans, the speaker employs a politeness register when talking about her older brother, who happens to be present at the time of speaking. ${ }^{4}$ This kind of pronominal politeness is known as REFERENT honorification and is contrasted with ADDRESSEE honorification where social deixis is marked between speech act participants, as in the tu/vous distinction in French (Levinson 1983: 90; see also Helmbrecht 2003; 2014). Addressee honorification exists both in the Indo-European languages spoken in southern Africa, i.e. Afrikaans, German and Portuguese, as well as some Bantu languages (see below). There is no evidence of addressee honorification in Tchoe. Another formal characteristic of the respect register in Tchoe involves the use of plural marking on the noun itself, seen in (11) above and in the next example on kinship nouns tata 'father' and mama 'mother'. Only the common gender plural PGN marker has

${ }^{4}$ The speaker does not show the employ the register with the other boy whose teasing of the speaker has provoked Ranamane to chase the boy away. 
this additional pragmatic function: the masculine and feminine counterparts always encode the number feature.
(12) ha tata-re
k'oxo mama-ra
gama-xo nyũũ
DEM father-C.PL.HON DI.PST mother-C.PL.HON.ACC leave-NMZ land
'The place [where] father long ago left mother.'

Pronominal honorification in 'Khoisan' languages is rare, and the attested cases may be due to language contact (see Haacke 2015: 70-71 for the possible effect of Afrikaans on Khoekhoe). ${ }^{5}$ It is, however, common in many regional Bantu (Niger-Congo) languages and, in contrast to Indo-European languages, referent honorification is not uncommon (see e.g. Johnston 1919). Given the many targets in Bantu morphosyntax which index number, honorific concord is much more pronounced than in Tchoe, as illustrated by the pair of sentences in (13) from Bemba (Bantu M40). The feature is found across Bantu languages in southern Africa, including Luvale (Bantu K10; Horton 1949: 184), Makwe (Bantu G40; Devos 2008), Nyanja (Bantu N30; Watkins 1937: 25), Makua (Bantu P30; Maugham 1898: 8), Kalanga (Bantu S10; Chebanne \& Schmidt 2010: 62ff.), Venda (Bantu S20; Poulos 1990: 20), Tsonga (Bantu S50; Baumbach 1987: 160), and Zulu (Bantu S42, de Kadt 1997: 100). In the examples below, morphemes glossed as CL1 and CL2 refer to the Bantu agreement class and nominal form class markers (for terminology see Güldemann \& Fielder, forthcoming) of the singular and plural classes for the human gender. The plural class is used with a singular referent in (13b) as part of a respect register in contrast to (13a).

(13) Bemba (Bantu M40, Niger-Congo) (Irvine 1992: 254-255)

$\begin{array}{llll}\text { a. } & \boldsymbol{u} \text {-mo u-mu-kalamba } & \boldsymbol{w a} \text {-andi } & \boldsymbol{a} \text {-lee-lya } \\ \text { CL1-one } & \text { AUG1-CL1-elder.sibling } & \text { CL1-1SG:POSS } & \text { 3sG-PRES-eat } \\ & \text { i-sabi } & & \\ \text { CL9-fish } & & \\ \text { 'One of my older siblings is eating fish.' }\end{array}$

${ }^{5}$ A respect register using lexical honorifics is found amongst the Khwe (Kalahari Khoe) of northern Namibia (Gertrud Boden, p.c.). 


\section{b. $\boldsymbol{b a}$-mo a-ba-kalamba ba-andi ba-lee-lya \\ CL2-one AUG2-CL2-elder.sibling CL2-1SG:POSS 3PL-PRES-eat i-sabi \\ CL9-fish \\ 'One of my older siblings is eating fish.' (ibid.)}

Pronominal honorification is not described in standard Tswana. However, it is attested in the Ngwato and Pedi varieties (see e.g. Ntshabele 1999: 56). These Tswana varieties are spoken by the groups with whom the Thabala Tchoe speech community have historical socio-economic ties (see §2.1). Thus, it can be said that contact between these two typologically very different languages has led a kind of 'pattern replication' (cf. Matras \& Sakel 2007). ${ }^{6}$

The diffusion of pronominal honorification into 'Khoisan' languages, particularly stigmatised minority languages like Tchoe, offers new insights on language dynamics and language ideology in the region. Such cases also speak against the presumption that "[pronominal honorification] is adopted or borrowed only in languages with a similar social structure" (Helmbrecht 2014: 332), as the social structures of the Bantu pastoralists and the Kalahari hunter-gatherers are different in fundamental ways. ${ }^{7}$

\section{2. "Emphatic" $1{ }^{\text {st }}$ person singular pronouns}

In Tchoe, there are two $1^{\text {st }}$ person pronominal forms in the nominative and accusative paradigms: simple or "unmarked" forms, tci (NOM) and tcia (ACC), and morphologically "marked" forms, tcire (NOM) and tcira (ACC). The difference between the unmarked and marked forms is the presence of $-r V$, an element which is suspiciously similar to the plural suffix, a point to which we return in due course.

${ }^{6}$ Phonological features, such as a lack of lateralised affricates and similar palatalisation patterns also point to the historical ties between these groups.

${ }^{7}$ Helmbrecht (2014: 332) also asks "if there were hunter and gatherer societies in the middle of Europe can it be speculated that they would not have borrowed this feature?" Pending further research, one could speculate a response in the negative. 
The example in (14) has instances of both the unmarked and marked nominative $1^{\text {st }}$ person singular pronouns. The utterance is an excerpt from a folktale about a tug-of-war between a hare and an elephant. The hare coerces the elephant into playing by insinuating that it is bound to win because the hare is much smaller.

\section{(14) tci kx'o tca ka mii tcire tca ?oa loa $e$ $1 \mathrm{sG}$ DI.PST $2 \mathrm{M} . \mathrm{SG}$ PST say $1 \mathrm{SG} . \mathrm{EMPH.NOM} 2 \mathrm{M}$.SG.ACC ? small COP 'I [the hare] told you that I am smaller than you.'}

The unmarked form tci is the subject/agent in a basic independent clause. The marked form tcire is the subject/agent in a complement clause. There is also a difference in the pragmatic value of the two subjects. In terms of information structure, the first clause is a categorical statement with a default topic-comment structure (see Lambrecht 1994): the subject serves as a canonical sentence topic encoding background information. The second clause is different: the subject/ agent referent tcire is contrasted with another discourse referent, tca ( $2 \mathrm{M} . \mathrm{SG}$ ), and is thus focal. In the utterance, the marked function of the focused subject/agent role correlates with the marked subject pronoun form.

A second example is given in (15), this time illustrating the marked form of the accusative pronoun. In this excerpt from another folktale, two farmers have chased a hare into a burrow. One of the farmers inserts his arm into the burrow and yells "I've caught him!" and then the hare yells back.

\section{(15) tca tcira xoo taa tca ka llari o xoo 2M.SG 1SG.EMPH.ACC catch NEG 2M.SG PST root ?FOC catch 'You have not caught ME, you have caught a ROOT!'}

In (15), the object referent tcira (1SG.ACC) of the first clause is contrasted with the object referent /Rari 'a [type of] root' in the second clause. This results in a pragmatically marked contrastive object focus constellation. 
A final example illustrating the use of the marked nominative $1^{\text {st }}$ person pronoun is given in (16). As with the previous two examples, the marked variant correlates with a pragmatically marked discourse context. The only difference is that the contrastive pair of referents is not made explicit in the utterance. Thus, when the speaker says '[it is] I [who] clean[s] the clothes', she relies on shared knowledge - namely that the hearer knows that the speaker is hired to clean - in order to contrast herself with another context-dependent referent.

\section{(16) tci tchoe-re ?ai Poa ko !ebe $x a$ ii tcire 1SG person-PL house LOC IPFV clean DEM DEM 1SG.EMPH ko xai xuu-re !ebe \\ IPFV dress thing-PL clean \\ 'I clean the people's house, [it is] I [who] clean[s] the clothes.'}

The analysis of the three examples above provides a functional account for the inventory of $1^{\text {st }}$ person singular pronominal forms in Tchoe. It remains only to explain the marking asymmetry in the pronominal system. In other words, why does a marked contrast exist only for the $1^{\text {st }}$ person singular?

A plausible explanation lies in the default interpretation of pronominal $1^{\text {st }}$ person singular subjects/agents as the most prototypical of overt sentence topics (Gívon 1983: 17). Some languages evolve strategies to disrupt this default interpretation, resulting in marking asymmetry (see Fiedler et al. 2010 for similar patterns in Chadic, Gur and Kwa languages).

Finally, subject-focus is not the only discourse context in which the marked nominative form tcire occurs. It is regularly used in elicitation when making strings of contextually unbound utterances that are free of any speaker-hearer presupposition, such as in (17). These are thetic utterances: single information units that lack an analysed state-of-affairs (Sasse 1987: 558).

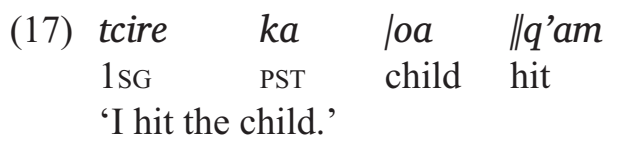


It might seem counter-intuitive that a focus strategy is employed in such a context. However, it is the ability to cancel the default topiccomment interpretation that makes it ideally suited to such thetic contexts. This form-to-function relationship exists throughout the Kalahari Basin (Güldemann 2010; Güldemann, Pratchett \& Witzlack-Makarevich 2019) and elsewhere in Africa (Fiedler et al. 2010).

\subsection{Innovative $3^{\text {rd }}$ person plural common gender PGNs}

The third feature of the pronominal system sets Tchoe apart from all other related languages. In every other Khoe language on record, the $3^{\text {rd }}$ person common gender PGN is a reflex of * $n V$ from Proto-Khoe (Vossen 1997 367-377). Hence I was initially perplexed by the presence presence of a non-cognate and morphologically more complex form -tere in Tchoe (see Table 2, §2.2). However, the form proves to be an elegant innovation that brings about system-internal harmony even if, externally, things first appear more complex.

To understand -tere we must first look at how contemporary Khoe languages came to be so complex. The pronominal system in the ancestral Proto-Khoe-Kwadi language was by comparison more simple. It possessed eight pronominal slots based on a so-called 'minimal-augmented' system (Güldemann 2004; forthcoming a). The inception of a genuine dual paradigm and substrate interference brought about considerable structural changes and diversification in the resulting early Khoe systems. Analogical levelling processes played an important role in the elaboration of the systems and the spread of morphologically complex PGNs. This is illustrated in Güldemann's (2004: 287-279) analysis of the development of the dual paradigm in three Khoe languages, repeated for convenience below and summarised in Table 3.

The Nama PGN system has reflexes of the simple items *m(u), *da-o, *da marking non-masculine. The only complex series, in *kho, is found in the masculine gender. I assume the Nama system to reflect the most conservative state of affairs.

!Ora continues to have complex forms with *kho in the masculine gender, but also has complex forms with *sa in the feminine gender. In 
the common gender there is a mixed pattern, with the base *kho having penetrated the $2^{\text {nd }}$ and $3^{\text {rd }}$ persons but not the 1 st person, which preserves the old simplex form *m(u).

Finally, in the Kalahari Khoe branch the process has reached completion: all the forms are complex, ${ }^{*}$ kho is now exclusively a common gender marker, *sa marks feminine, and a new marker *tsa has penetrated the masculine paradigm.

(Güldemann 2004: 278-279)

The above analysis avoids reconstructing highly complex systems to an ancestor language and demonstrates the tendency for languages to undergo "maximal systemic elaboration where all possible distinctions arising from combining the three features person, gender, and number are marked" (Güldemann 2004: 299).

Table 4 gives the PGN paradigms in Proto-Kalahari Khoe and Tchoe. By approaching the data with a greater sensibility for analogical levelling, a pattern in the modern Tchoe system becomes clear: the morpheme initial consonant has harmonised across all three persons towards $-t$. This is indicative of analogical levelling towards $-t a$, in line with the pattern in the $1^{\text {st }}$ and $2^{\text {nd }}$ person forms.

Conceivably, the innovative PGN hosts additional number marking, which explains the additional CV segment that is identical to the plural marker -re. Regarding the phonological shape of the innovative form, there are two plausible hypotheses. The most straightforward deconstruction of the new form involves postulating a sound change triggered by the vowel in the suffix *-ta-re > -tere. However, this would not explain the emergent accusative form -tua (see Table 2, §2.2). Instead, it seems more likely that the analogy is based on the masculine paradigm and involved copying the masculine number marker $-u$ (*-ta-u-re). A similar pattern is attested in the development of the dual paradigm in Khoe (Güldemann 2004: 279-287).

The semantic extension of e.re from $3^{\text {rd }}$ person common gender plural to an honorific pronoun for singular referents also provides a functional impetus for the development, namely the need for a nonambiguous $3^{\text {rd }}$ person plural. However, the innovative form comes with 
Table 3

Dual PGNs in Khoe languages (after Güldemann 2004: 278)

\begin{tabular}{|c|c|c|c|c|}
\hline $\begin{array}{c}\text { Language } \\
\text { (group) }\end{array}$ & Person & $\begin{array}{l}\text { Gender } \\
\text { Common }\end{array}$ & Feminine & Masculine \\
\hline \multirow{3}{*}{ Nama } & 1 & $\grave{m}$ & $\grave{m}$ & $\begin{array}{l}\text { kxì } \\
{[<* \text { kho }+\mathrm{m}]}\end{array}$ \\
\hline & 2 & rò & rò & $\begin{array}{l}\text { kxò } \\
{[<* \text { kho + da-o }]}\end{array}$ \\
\hline & 3 & rà & rà & $\begin{array}{l}\text { kxà } \\
{[<* \text { kho }+ \text { da }]}\end{array}$ \\
\hline \multirow{3}{*}{ !Ora } & 1 & $m$ & $\begin{array}{l}\operatorname{sam} \\
{[<* s a+\mathrm{m}]}\end{array}$ & $\begin{array}{l}\text { kham } \\
{[<* \text { kho }+\mathrm{m}]}\end{array}$ \\
\hline & 2 & khao & $\begin{array}{l}\text { saro } \\
{[<* \text { sa }+ \text { da-o }]}\end{array}$ & $\begin{array}{l}\text { kharo } \\
{[<* \text { kho + da-o }]}\end{array}$ \\
\hline & 3 & kha & $\begin{array}{l}\operatorname{sara} \\
{[<* \text { sa }+\mathrm{da}]}\end{array}$ & $\begin{array}{l}\text { khara } \\
{[<* \text { kho + da }]}\end{array}$ \\
\hline \multirow{3}{*}{$\begin{array}{l}\text { Proto- } \\
\text { Kahalari } \\
\text { Khoe }\end{array}$} & 1 & *kho-m & *sa-m & *tsa-m \\
\hline & 2 & *kho-da-o & ${ }^{*} s a-d a-o$ & *tsa-da-o \\
\hline & 3 & *kho-da & *sa-da & *tsa-da \\
\hline
\end{tabular}

Table 4

Plural PGNs in Proto-Kalahari Khoe and Thabala Tchoe lect

\begin{tabular}{|c|c|c|c|c|}
\hline Language & Person & $\begin{array}{c}\text { Gender } \\
\text { Common }\end{array}$ & Feminine & Masculine \\
\hline \multirow{3}{*}{$\begin{array}{l}\text { Proto } \\
\text { Kalahari- } \\
\text { Khoe }\end{array}$} & 1 & *ta -e & ${ }^{*} s a-e$ & $* ! a-e$ \\
\hline & 2 & *ta -o & ${ }^{*} s a-o$ & $* ! a-o$ \\
\hline & 3 & ${ }^{*} n V$ & $* d i$ & $* ! a-u(>* ! u)$ \\
\hline \multirow{3}{*}{$\begin{array}{l}\text { Thabala } \\
\text { Tchoe }\end{array}$} & 1 & $-t a$ & $-s i e \sim s e \sim z e$ & $-k a$ \\
\hline & 2 & $-t a o$ & $-d z a o$ & $-k a o$ \\
\hline & 3 & -tere $(<*$ ta-u-re $)$ & $-d z e$ & $-k u e(<*$ ka-u-e $)$ \\
\hline
\end{tabular}


an animacy constraint and, as such, Tchoe diverges from related languages by encoding an animacy distinction in the $3^{\text {rd }}$ person plural pronouns.

Table 5

Animacy distinction in $3^{\text {rd }}$ person common gender pronouns in Thabala Tchoe

\begin{tabular}{|c|c|c|}
\hline & Singular & Plural \\
\hline$e$ & non-human & - \\
\hline e.re & human (respectful) & non-human \\
\hline e.tere & - & human common gender \\
\hline
\end{tabular}

\subsection{Implications and reflections on genealogy}

Not everything that is divergent about Tchoe is necessarily due to innovation. On the contrary, formal aspects of some PGN forms suggest a more conservative status. This is illustrated in the following with a brief comparison of Tchoe with Southern Tshwa and Northern Tshwa. As the difference between the three Southern Tshwa lects - Kua, Tsua, and Cua - is minimal (sometimes only tone), the Tsua lect is used here as a point of reference (data from Chebanne 2014). The Northern Tshwa system is represented by Tjwao (data from Fehn \& Phiri 2017).

Fehn \& Phiri (2017: 120) draw attention to the absence in Northern Tshwa of the clusivity feature, marked elsewhere by contrastive pronominal bases. This is linked to the more general lack of complex pronouns in Northern Tshwa, i.e. pronouns formed with a pronominal base and a PGN. It has been suggested that the predominance of complex pronouns, as remarked in Southern Tshwa and Tchoe, is likely to be another instance of analogical levelling (Güldemann, forthcoming a). Thus, Northern Tshwa represents a more conservative version of the language in this regard.

Looking more closely at the Southern Tshwa forms, one will notice that they all terminate in $-e$, quite unlike Tchoe or Northern Tshwa. Conceivably, nominative PGNs adopted a final vowel modelled on the pattern found on accusative PGNs which have the final vowel $-a$. 
$\frac{\sqrt{0}}{0}$

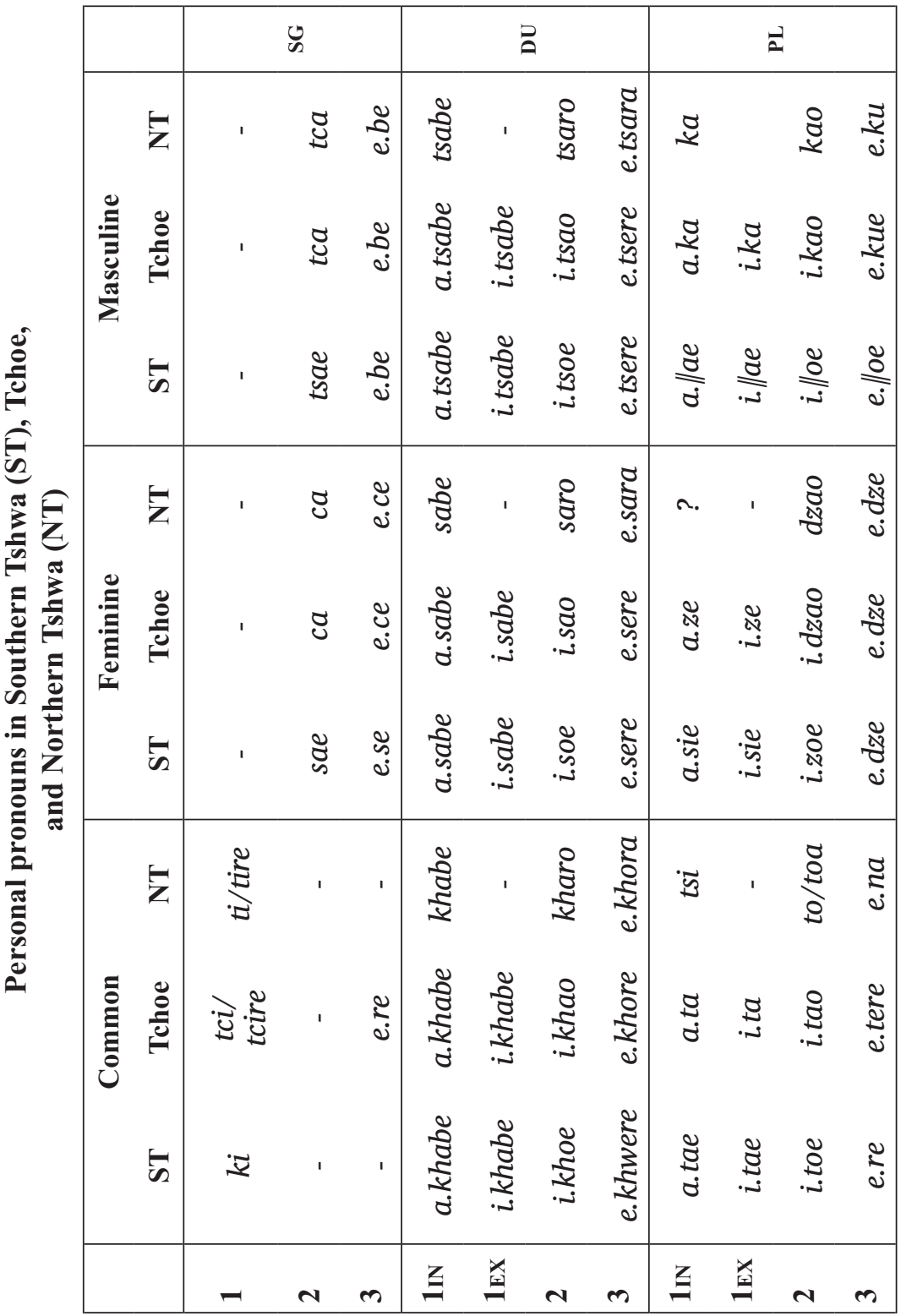


This suggests innovation in Southern Tshwa and relative conservativism in Tchoe and a mostly conservative Northern Tshwa.

The conservative nature of Northern Tshwa is clearest in the morphophonological shape of particular PGNs. Table 7 gives the forms for the $2^{\text {nd }}$ person common gender dual and $2^{\text {nd }}$ person masculine gender plural. In both cases, Northern Tshwa has retained the most morphological material inherited from the ancestral language.

Table 7

Reduction in morphological complexity of two pronominal forms across Kalahari Khoe

\begin{tabular}{|l|c|c|c|c|}
\hline & Proto-Kalahari Khoe & Northern Tshwa & Tchoe & Southern Tshwa \\
\hline 2C.DU & $* k h o-d a-o$ & $-k h a r o$ & $-k h a o$ & $-k h o(e)$ \\
\hline 2M.PL & $* ! a-o^{8}$ & $-k a o$ & $-k a o$ & $-\| o(e)$ \\
\hline
\end{tabular}

In Southern Tshwa, the PGN forms in Table 7 either show no morphophonological trace of the original number marker, i.e. ${ }^{*} d a$ in $-k h o$ $(<*$ kho-da-o), or the number marker has become fused with the gender marker, as in $-\| o(<*$ !a-o). In Tchoe, the constituent parts are still recognisable, albeit phonologically reduced and assimilated.

There is one aspect of the Southern Tshwa inventory that is demonstrably more conservative than the other varieties, namely click retention in the masculine PGN forms. However, far from being an indicator of anteriority, the retention of the lateral click in Southern Tshwa indicates that phonological change, i.e. click replacement, and morphological change are independent of one another. As far as anteriority is concerned, the easternmost varieties, i.e. Northern Tshwa, retain more of the most of the ancestral profile of Kalahari Khoe. This is in keeping with modern views on the spread of the Khoe language into the Kalahari Basin (see Güldemann, forthcoming $b$ ).

${ }^{8}$ Vossen (1997: 377) reconstructs an lateral click, *[\|a] based on large scale comparison of Khoe languages whilst Güldemann (2004: 265) reconstructs an alveolar click *[!a] based on hypothetical contact with a non-Khoe language. 
It is beyond the goals of the present study to provide a categorical classification of Tchoe. There are, however, aspects of the pronominal systems that are suggestive of deeper ties between Tchoe and Northern Tshwa (see also Pratchett 2018). Contact between different lects from across the region, a result of the complex history summarised only briefly in $\S 2.1$, motivates areal effects. This is a plausible explanation for the many affinities between Tchoe and Southern Tshwa, including perhaps also the clusivity feature.

\section{Conclusion}

Thabala Tchoe is the only Khoe language on record in which the plural common gender PGNs have undergone complete harmonisation mirroring processes largely complete in the masculine and feminine paradigms. Thabala Tchoe is also the first Khoe language in which (referential) pronominal honorification is attested. Finally, the presence the presence of marked forms of the $1^{\text {st }}$ person singular pronouns can be explained in information structural terms. This may be of interest for the study of other Khoe languages in which so-called "emphatic" pronouns are described (e.g. in Naro, see Barnard 1979: 85).

An especially interesting aspect of the innovations in Tchoe is the apparent synchronic multifunctionality of what I suppose to be a single grammeme historically. We have seen how $-r V$ encodes a number distinction (sometimes linked to animacy), a politeness distinction, subjectfocus, and theticity in Tchoe, illustrating the clear convergence of convergence of formal and functional markedness.

Recent studies on the diversity of the Kalahari Khoe languages in eastern Botswana have used descriptions of the pronominal systems to formulate hypotheses about about Tshwa-internal classification (e.g. Chebanne 2014; Chebanne \& Collins 2017; Fehn \& Phiri 2017). None of these studies included a variety that exhibited the kind of divergence found in Tchoe. Fehn \& Phiri (2017) posit a Southern and Northern Tshwa dialect cluster and although Tchoe shares features with both, it diverges significantly due both to contact and language internal develop- 
ments. It is perhaps no coincidence that, geographically, the Thabala community lies somewhat in the middle of the two micro-areas. Forthcoming research comparing the pronominal systems of ten different varieties will provide a more fine-grained analysis. Ultimately, a sound classification will depend on more than pronouns, particularly if, as shown here, they are so prone to change.

\section{Acknowledgements}

This research was funded by the Endangered Languages Documentation Programme (ELDP, grant no. IPF0239) with additional support from Japanese Society for the Promotion of Science (KAKENHI, grant no. $16 \mathrm{H} 01925$ and 25300029). Parts of this study have been presented at the 23. Afrikanistentag, Hamburg University, 2018; the International Conference of Linguists, Cape Town, 2018; and at the University of Botswana, 2018. Many thanks are owed to language consultants in Botswana, particularly Ranamane Abae and Lerothodi Nkatse. Additional thanks go to Ines Fiedler, Viktoria Apel, and to two anonymous reviewers, for their feedback and comments on earlier drafts of this paper.

\section{Abbreviations}

\begin{tabular}{|c|c|c|}
\hline ACC - accusative & FOC - focus & NT - Northern Tshwa \\
\hline AUG - augment & GEN - genitive & PL - plural \\
\hline $\mathrm{C}$ - common gender & HON - honorific & $\mathrm{PN}$ - proper name \\
\hline $\mathrm{CL}$ - agreement class & HORT - hortative & POSS - possessive \\
\hline COP - copula & $\mathrm{IN}$ - inclusive & PRES - present \\
\hline DEM - demonstrative & IPFV - imperfective & PST - past \\
\hline DI.PST - distant past & LOC- locative & $\mathrm{SG}-$ singular \\
\hline DU - dual & $\mathrm{M}$ - masculine gender & ss - same subject \\
\hline EMPH - emphatic & NEG - negation & ST - Southern Tshwa \\
\hline EX - exclusive & NMZ - nominalizer & v-vowel \\
\hline $\mathrm{F}$ - feminine gender & NOM - nominative & NT - Northern Tshy \\
\hline
\end{tabular}




\section{References}

Barnard, Alan. 1985. A Nharo wordlist, with notes on grammar. Durban: University of Kwa-Zulu Natal, Department of African Studies.

Baumbach, Erdmann J. M. 1987. Analytical Tsonga grammar. Pretoria: University of South Africa.

Brown, Penelope \& Levinson, Stephen C. 1987. Politeness: some universals in language usage. Cambridge: Cambridge University Press

Campbell, Alec \& Main, Michael \& Hitchcock, Robert K. 2006. Land, livestock, and labour in rural Botswana: The Western Sandveld Region of Central District as a case study. In Hitchcock, Robert K. \& Ikeya, Kazunobu \& Biesele, Megan \& Lee, Richard B. (eds.), Updating the San: Image and reality of an African people in the 21st century (Senri ethnological studies 70), 183-228. Osaka: National Museum of Ethnology.

Chebanne, Andy. 2014. What have Eastern Kalahari Khoe languages lost linguistically? Stellenbosch Papers in Linguistics Plus 44. 1-21.

Chebanne, Andy \& Collins, Chris. 2017. Tense and aspect in Kua: a preliminary assessment. In Fehn, Anne Maria (ed.), Khoisan languages and linguistics: proceedings of the $4^{\text {th }}$ international symposium, July 11-13, 2011, Riezlern/Kleinwalsertal, 91-108. Cologne: Rüdiger Köppe.

Chebanne, Andy \& Schmidt, Daniel. 2010. Kalanga: summary grammar. Cape Town: Centre for Advanced Studies of African Society.

de Kadt, Elizabeth. 1994. Towards a model for the study of impoliteness in Zulu. South African Journal of African languages 14(3). 103-112.

Devos, Maud. 2008. A grammar of Makwe (Palma, Mozambique). München: Lincom Europa.

Fehn, Anne-Maria. 2018. New data on northeastern Kalahari Khoe phoneme inventories - a comparative survey. Africana linguistica 24. 5-29. (= In Güldemann, Tom \& Nakagawa, Hirosi (eds.), Kalahari Basin sound structure - in memory of Anthony T. Traill.)

Fehn, Anne-Maria. 2016. A grammar of Ts'ixa (Kalahari Khoe). Cologne: University of Cologne. (Doctoral dissertation.)

Fehn, Anne-Maria \& Phiri, Admire. 2017. Nominal marking in Northern Tshwa (Kalahari Khoe). Stellenbosch Papers in Linguistics 48. 105-122.

Fiedler, Ines \& Hartmann, Katharina \& Reineke, Brigitte \& Schwarz, Anne \& Zimmermann, Malte. 2010. Subject focus in West African languages. 
In Zimmermann, Malte \& Féry, Caroline (eds.), Information structure: theoretical, typological and experimental perspectives, 234-257. Oxford: Oxford University Press.

Givón, Talmy. 1983. Topic continuity in discourse: an introduction. In Givón, Talmy (ed.), Topic continuity in discourse: a quantitative cross-language study, 5-41. Amsterdam: John Benjamins.

Güldemann, Tom. Forthcoming a. Person-gender-number marking from Proto-Khoe-Kwadi to its descendants: a rejoinder with particular reference to language contact. In Vossen, Rainer \& König, Christa (eds.), Patterns of linguistic convergence in Africa. [Frankfurter Afrikanistische Blätter 27 (2015).]

Güldemann, Tom. Forthcoming b. Changing profile when encroaching on hunter-gatherer territory: towards a history of the Khoe-Kwadi family in southern Africa. In Güldemann, Tom \& McConvell, Patrick \& Rhodes, Richard (eds.), Hunter-gatherers and linguistic history: A global perspective. Cambridge: Cambridge University Press.

Güldemann, Tom. 2014. Introduction: 'Khoisan' linguistic classification today. In Güldemann, Tom \& Fehn, Anne-Maria (eds.), 'Beyond Khoisan': historical relations in the Kalahari Basin, 1-41. Amsterdam: John Benjamins.

Güldemann, Tom. 2010. The relation between focus and theticity in the Tuu family. In Fiedler, Ines \& Schwarz, Anne (eds.), The expression of information structure: a documentation of its diversity across Africa (Typological Studies in Language 91), 69-93. Amsterdam: John Benjamins.

Güldemann, Tom. 2004. Reconstruction through 'de-construction': the marking of person, gender, and number in the Khoe family and Kwadi. Diachronica 21(2). 251-306.

Güldemann, Tom \& Fiedler, Ines. Forthcoming. Niger-Congo "noun classes" conflate gender with deriflection. In Di Garbo, Francesca \& Wälchli, Bernhard (eds.), Grammatical gender and linguistic complexity, 85135. Berlin: Language Science Press.

Güldemann, Tom \& Pratchett, Lee J. \& Witzlack-Makarevich, Alena. 2019. From pragmatics to sentence type: non-topical S/A arguments and clause-second particles in the Kalahari Basin. Gengo Kenkyu (Journal of the linguistics society of Japan) 154. 53-84. 
Güldemann, Tom \& Elderkin, E. D. 2010. On external genealogical relationships of the Khoe family. In Brenzinger, Mathias \& König, Christa (eds.), Khoisan languages and linguistics: proceedings of the $1^{\text {st }}$ international symposium, January 4-8, 2003, Riezlern/Kleinwalsertal, 15-52. Cologne: Rüdiger Köppe.

Haacke, Wilfrid H. G. 2015. Lexical borrowing by Khoekhoegowab from Cape Dutch and Afrikaans. Stellenbosch papers in linguistics plus 47. 59-74.

Helmbrecht, Johannes. 2003. Politeness distinction in second person pronouns. In Lenz, Friedrich (ed.), Deictic conceptualisation of space, time and person, 185-203. Amsterdam: John Benjamins.

Helmbrecht, Johannes. 2013. Politeness distinctions in pronouns. In Dryer, Matthew S. \& Haspelmath, Martin (eds.), The world atlas of language structures online. Leipzig: Max Planck Institute for Evolutionary Anthropology. (Available online at http://wals.info/chapter/45, Accessed on 2019-10-13.)

Helmbrecht, Johannes. 2014. Politeness distinctions in personal pronouns a case study in competing motivations. In MacWhinney, Brian \& Malchukov, Andrej \& Moravcsik, Edith (eds.), Competing motivations in grammar and usage, 315-333. Oxford: Oxford University Press.

Hitchcock, Robert K. 1978. Kalahari cattle posts: a regional study of huntergatherers, pastoralists and agriculturalists in the Western Sandveld Region, Central District, Botswana. Gaborone, Botswana: Government Printer.

Hitchcock, Robert K. \& Nangati, Fanuel M. 2000. People of the two-way river: socioeconomic change and natural resource management in the Nata River region of Southern Africa. Botswana Notes and Records 32. $1-21$.

Horton, A. E. 1949. A grammar of Luvale. Johannesburg: Witwatersrand University Press.

Irvine, Judith T. 1992. Ideologies of honorific language. Pragmatics 2(3). 251-262.

Johnston, Harry H. 1919. A comparative study of the Bantu and Semi-Bantu languages. Oxford: Oxford University Press.

Lambrecht, Knud. 1994. Information structure and sentence form: Topic, focus, and the mental representation of discourse referents. Cambridge: Cambridge University Press. 
Levinson, Stephen C. 1983. Pragmatics. Cambridge: Cambridge University Press.

Mathes, Timothy K. 2015. Consonant-tone interaction in the Khoisan language Tsua. New York: New York University. (PhD thesis.)

Matras, Yaron \& Sakel, Jeanette. 2007. Investigating the mechanisms of pattern replication in language convergence. Studies in language 31(4). 829-865.

Maugham, Reginald C. F. 1898. A handbook of the Chi-Makua language. University of Manchester: The John Rylands University Library.

Meinhof, Carl. 1930. Der Koranadialekt des Hottentottischen. Hamburg: Eckardt \& Messtorff. (= Zeitschrift für Eingeborenen Sprachen, Beiheft 12.)

Morton, Fred \& Murray, Andrew \& Ramsay, Jeff. 1989. Historical dictionary of Botswana. New Jersey: The Scarecrow Press, Inc.

Ntshabele, Carol Mmamonyana. 1999. Language variation in the Botswana speech community and its impact on children's education. Cape Town: University of Cape Town. (Master's thesis.)

Parsons, Neil. 1993. A concise history of Southern Africa. London: Macmillan.

Parsons, Neil. 1974. The economic history of Khama's country in southern Africa. African Social Research (Lusaka) 18. 643-673.

Poulos, George. 1990. A linguistic analysis of Venda. Pretoria: Via Afrika.

Pratchett, Lee J. 2018. A new appraisal of dialect diversity in Tshwa (Kalahari-Khoe). Paper presented at the Afrikalinguistisches Kolloquium, Humboldt University of Berlin, 15.05.2018.

Roulon-Doko, Paulette. 1997. Parlons gbaya. Paris: L'Harmattan.

Sasse, Hans-Jürgen. 1987. The thetic/categorical distinction revisited. Linguistics 25. 511-580.

Trail, Anthony \& Vossen, Rainer. 1997. Sound change in the Khoisan languages: new data on click loss and click replacement. Journal of African Languages and Linguistics 18. 21-56.

Valiente-Noailles, Carlos. 1993. The Kua: life and soul of the Central Kalahari Bushmen. Rotterdam: A. A. Balkema.

Vossen [Voßen], Rainer. 1997. Die Khoe-Sprachen: Ein Beitrag zur Erforschung der Sprachgeschichte Afrikas. Cologne: Rüdiger Köppe. 
Watkins, Mark Hanna. 1937. A grammar of Chichewa: A Bantu language of British Central Africa. Language 13 (2), Language Dissertation No. 24. 5-7, 9-158.

Wilmsen, Edwin. 1989. Land filled with flies: a political economy of the Kalahari. Chicago: The University of Chicago Press. 